\title{
Evidence for Sexual Reproduction: Identification, Frequency, and Spatial Distribution of Venturia effusa (Pecan Scab) Mating Type Idiomorphs
}

\author{
Carolyn A. Young, ${ }^{+}$Clive H. Bock, Nikki D. Charlton, Chakradhar Mattupalli, Nick Krom, Joanna K. Bowen, \\ Matthew Templeton, Kim M. Plummer, and Bruce W. Wood
}

First, third, fourth, and fifth authors: Noble Research Institute, LLC., Ardmore, OK 73401; second and ninth authors: United States Department of Agriculture-Agricultural Research Service Southeastern Fruit and Tree Nut Research Laboratory, Byron, GA 31008; sixth and seventh authors: The New Zealand Institute for Plant \& Food Research, Auckland, New Zealand; seventh author: The School of Biological Sciences, University of Auckland, New Zealand; eighth author: Department of Animal, Plant and Soil Sciences, AgriBio, AgriBiosciences Research Centre, La Trobe University, 3086, Victoria, Australia.

Accepted for publication 27 January 2018.

\begin{abstract}
Venturia effusa (syn. Fusicladium effusum), causal agent of pecan scab, is the most prevalent pathogen of pecan (Carya illinoinensis), causing severe yield losses in the southeastern United States. V. effusa is currently known only by its asexual (conidial) stage. However, the degree and distribution of genetic diversity observed within and among populations of $V$. effusa are typical of a sexually reproducing fungal pathogen, and comparable with other dothideomycetes with a known sexual stage, including the closely related apple scab pathogen, V. inaequalis. Using the mating type (MAT) idiomorphs from $V$. inaequalis, we identified a single MAT gene, MAT1-1-1, in a draft genome of V. effusa. The MAT1-1-1 locus is flanked by two conserved genes encoding a DNA lyase (APN2) and a hypothetical protein. The MAT locus spanning the flanking genes was

amplified and sequenced from a subset of 14 isolates, of which 7 contained MAT1-1-1 and the remaining samples contained MAT1-2-1. A multiplex polymerase chain reaction screen was developed to amplify MAT1-1-1, MAT1-2-1, and a conserved reference gene encoding $\beta$-tubulin, and used to screen 784 monoconidial isolates of V. effusa collected from 11 populations of pecan across the southeastern United States. A hierarchical sampling protocol representing region, orchard, and tree allowed for analysis of MAT structure at different spatial scales. Analysis of this collection revealed the frequency of the $M A T$ idiomorphs is in a $1: 1$ equilibrium of MAT1-1:MAT1-2. The apparent equilibrium of the MAT idiomorphs provides impetus for a renewed effort to search for the sexual stage of V. effusa.
\end{abstract}

Scab is the most prevalent disease of pecan (Carya illinoinensis (Wang.) K. Koch) in the southeastern United States (Demaree 1924). Estimated crop losses in the state of Georgia alone were 15, 10 , and $12 \%$ in 2013, 2014, and 2015, respectively (Brock and Brenneman 2013, 2014, 2015). The combined cost of the damage and disease control measures was $\$ 78.7, \$ 25.7$, and $\$ 65$ million in these 3 years, respectively. The disease is caused by the plantpathogenic fungus Venturia effusa (G. Winter) Rossman \& W. C. Allen (Rossman et al. 2016; Schubert et al. 2003; Seyran et al. 2010a), whereby infection by the pathogen can cause serious and even catastrophic yield loss when conditions are favorable for an epidemic (Gottwald and Bertrand 1983; Stevenson and Bertrand 2001).

Venturia effusa was first isolated from mockernut (C. alba = C. tomentosa) in Illinois (Winter 1885), and is described causing disease on C. aquatica, C. cordiformis (=C. amara), C. glabra, and C. ovata (Schubert et al. 2003). Along with C. illinoinensis, these Carya spp. are native to the southeastern United States but pecan is the only cultivated species. The native extent of pecan is thought to be primarily the Mississippi watershed area (Worley 2002), while

${ }^{\dagger}$ Corresponding author: C. A. Young; E-mail: cayoung@noble.org

Funding: Support for the research was provided through USDA-ARS project number 6042-21220-012-00 to C. H. Bock and B. W. Wood and through Noble Research Institute, LLC to C. A. Young.

C. A. Young and C. H. Bock are joint first authors.

*The $\boldsymbol{e}$-Xtra logo stands for "electronic extra" and indicates that two supplementary tables are published online.

Copyright (C) 2018 The Author(s). This is an open access article distributed under the CC BY-NC-ND 4.0 International license. the remaining Carya spp. are of scattered distribution. Since the mid-19th century, pecan has been cultivated mostly as clonal cultivars on rootstocks, although some production of native trees still exists. Much of the acreage in the southeastern United States is planted to susceptible cultivars and, thus, the disease is a major concern in most years.

$V$. effusa relies on wind and rain splash to spread conidia early in the season (Gottwald and Bertrand 1982). The primary source of inoculum, thought to be conidia, comes from overwintering lesions on shoots and shucks from the previous year (Demaree 1924). In the spring, as conditions become favorable for sporulation, conidia spread to the expanding leaves and cause infection on the foliage. In seasons conducive to the disease, the pathogen can reproduce asexually in as little as 7 to 9 days, and this can happen multiple times throughout the growing season (Latham 1982). As the fruit are produced, they can become infected, and the earliness and severity of infection will dictate the degree of yield loss (Gottwald and Bertrand 1983; Stevenson and Bertrand 2001).

Pecan scab is a challenging disease to manage (Bock et al. 2017a); over time, V. effusa has developed resistance to several major classes of fungicides recommended for its management, including both single-site and multisite chemistries (Seyran et al. 2010b). Although scab-resistant pecan cultivars are available, they are often not preferred by either growers or consumers for agronomic or nut quality reasons. Additionally, there is a history of the resistance breaking down as the pathogen population adapts to host resistance (Goff et al. 1989). Furthermore, isolates of $V$. effus $a$ have a race structure based around the pecan cultivar on which they originated and other closely related cultivars; however, the race structure has not been fully examined (Conner and Stevenson 2004; Converse 1960). The degree and distribution of genetic diversity observed within and among populations of $V$. effusa (Bock et al. 
2014a,b, 2016a, 2017b) reflect that of other sexually reproducing fungal pathogens, including the closely related $V$. inaequalis, cause of apple scab (Keitt and Palmiter 1938; Tenzer and Gessler 1999).

The mating type (MAT) locus in fungi is known to control sexual reproduction. In ascomycetes, the MAT locus consists of two idiomorphs, MAT1-1 and MAT1-2, which can be distinguished by the presence of either a gene that encodes an $\alpha$-box protein, as found in MAT1-1 (gene = MAT1-1-1), or a high mobility group (HMG) DNA binding protein encoded by MATl-2 (gene = MAT1-2-1) (Turgeon and Yoder 2000). MAT genes have been identified in many species (Pöggeler 2001) using polymerase chain reaction (PCR) with degenerate primers (Arie et al. 1997) and, more recently, they have been readily identified within genome sequences (Pearce et al. 2016; Penselin et al. 2016). Comparative analyses of the gene organization surrounding the MAT loci have shown that, although some synteny of the flanking genes can exist, variation occurs across the ascomycetes (Debuchy and Turgeon 2006).

Identification of different MAT idiomorphs (MAT1-1 and MAT1-2) in a population and ascertaining whether the two mating types are in equilibrium can provide evidence for a heterothallic mating system, which can influence pathogen population genetics. MAT equilibrium has been demonstrated for many other sexually reproducing fungal pathogens in the class Dothideomycetes; for example, Dothistroma septosporum, Leptosphaeria maculans, Zymoseptoria tritici, Pyrenophora teres, and Phaeosphaeria nodorum (Dale et al. 2011; Hayden and Howlett 2005; Linde et al. 2002; Rau et al. 2005; Sommerhalder et al. 2006). Aspergillus flavus and Neosartorya fumigata were once assumed to be asexual species until studies established that populations retained MAT idiomorphs that were often in equilibrium, which paved the way to the discovery of the sexual stage and a fuller understanding of the pathogen population biology (Horn et al. 2009; O'Gorman et al. 2009; Ramirez-Prado et al. 2008).

The pecan scab pathogen has demonstrated the ability to adapt to novel host resistance, and the observed genetic diversity across populations suggests a method for generating and maintaining variability. These characteristics are consistent with fungal populations that have the capability to recombine sexually. The recent genome sequence of an isolate of $V$. effusa and the discovery of a potential $M A T$ gene (Bock et al. 2016b) has provided the impetus to determine whether this pathogen has the potential for sexual recombination. Here, we describe the identification of V. effusa MAT idiomorphs, the development of MAT markers, and a screening protocol for isolates of V. effusa. We also assess diverse populations previously characterized by simple-sequence repeat (SSR) markers (Bock et al. 2017b) for the ratios of the MAT idiomorphs at different spatial scales in the southeastern United States.

\section{MATERIALS AND METHODS}

Sample locations and isolation of $\boldsymbol{V}$. effusa. The isolates of $V$. effusa ( $n=784$ isolates) characterized for MAT idiomorphs are based on the collections that have been previously evaluated for population genetic structure using SSR markers (Bock et al. 2017b). Isolation of $V$. effusa was done as previously described by Bock et al. (2014a,b). Isolates of $V$. effusa were obtained from scabdiseased leaves from 11 populations across the southeastern United States (Table 1; Fig. 1). Samples were collected from different cultivars using a hierarchical sampling protocol that was followed at all sites so that the $M A T$ structure at different spatial scales could be assessed, with the largest scale being that of the region. There were 11 orchards with six trees sampled in each orchard (except in Kansas, where only three trees were sampled). Up to 19 individual scab lesions were sampled per tree, each from one leaflet on a different compound leaf. Thus, the sampling comprised the regional scale, between orchard locations (106 to $1,321 \mathrm{~km})$, between trees within an orchard (50 to $140 \mathrm{~m}$ ), and between leaflets within a tree canopy ( 2 to $20 \mathrm{~m}$ ). Trees were separated by at least four rows and sampled on a grid basis, where orchard shape and size allowed. The isolates were sampled from both commercially available cultivars in orchards and naturally seeded native-tree groves. A subset of 14 monoconidial isolates was selected, representing different locations and cultivars, to sequence the MAT idiomorphs (Table 1).

DNA extraction. DNA was extracted from mycelium scraped off a colony growing on potato dextrose agar using the Quick-DNA Fungal/Bacterial Miniprep Kit (ZymoResearch, Irvine, CA), with slight modification (Seyran et al. 2010a). A TissueLyser (Qiagen, Valencia, CA) was used to lyse the fungal mycelium. The DNA was quantified using a Nanodrop spectrophotometer (Nanodrop Products, Wilmington, DE) and stored in Tris-EDTA buffer at $-20^{\circ} \mathrm{C}$.

Genome sequences and sequence analyses. A draft genome sequence of $V$. inaequalis was generated by Plant and Food Research, New Zealand (Deng et al. 2017) and accessed with permission by Dr. Joanna Bowen (Plant and Food Research, New Zealand) through the Joint Genome Institute Genome Portal (Nordberg et al. 2014) and through GenBank BioProject PRJNA261633. Additional genomes of $V$. inaequalis races were generated by Plant and Food Research, New Zealand and La Trobe University. The GenBank accession numbers for $V$. inaequalis MAT1-1 and MAT1-2 are MG818328 and MG818329, respectively.

The genome sequence of $V$. effusa isolate 3Des $10 \mathrm{~b}$ from the cultivar Desirable is available under GenBank BioProject PRJNA285422 (Bock et al. 2016b). Once we had established the mating type of the subset of 14 isolates, we selected 1 isolate that represented the opposite mating type to 3 Des $10 \mathrm{~b}$ to complete the flanking regions of

TABLE 1. Location, elevation, source cultivar, and number of isolates of Venturia effusa collected to assess mating type in the southeastern United States ${ }^{\text {a }}$

\begin{tabular}{|c|c|c|c|c|c|c|c|}
\hline $\begin{array}{l}\text { Source population } \\
\text { (town, state) }\end{array}$ & $A b b r^{b}$ & $N^{\mathrm{c}}$ & 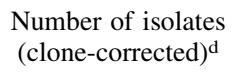 & Latitude and longitude of site & Elevation (m) & Pecan cultivar & Year (month) \\
\hline Fairhope, AL & AL-F & 6 & $93(92)$ & $30^{\circ} 32.681^{\prime} \mathrm{N} / 87^{\circ} 52.918^{\prime} \mathrm{W}$ & 62 & Desirable & 2012 (June) \\
\hline Lowndesboro, $\mathrm{AL}^{\mathrm{e}}$ & AL-L & 6 & $91(83)$ & $32^{\circ} 21.236^{\prime} \mathrm{N} / 86^{\circ} 38.393^{\prime} \mathrm{W}$ & 43 & Kiowa & 2012 (June) \\
\hline Chetopa, KS & KS-C & 3 & $34(33)$ & $37^{\circ} 01.360^{\prime} \mathrm{N} / 95^{\circ} 02.783^{\prime} \mathrm{W}$ & 266 & Native seedling & 2011 (July) \\
\hline Powhatan, LA ${ }^{\mathrm{e}}$ & LA-P & 6 & $68(66)$ & $31^{\circ} 50.211^{\prime} \mathrm{N} / 93^{\circ} 13.328^{\prime} \mathrm{W}$ & 33 & Desirable & 2011 (July) \\
\hline Raymond, MS & MS-R & 6 & $89(80)$ & $32^{\circ} 11.297^{\prime} \mathrm{N} / 90^{\circ} 29.537^{\prime} \mathrm{W}$ & 70 & Desirable & 2012 (June) \\
\hline Monticello, FL & FL-M & 6 & $52(50)$ & $30^{\circ} 32.265^{\prime} \mathrm{N} / 83^{\circ} 55.060^{\prime} \mathrm{W}$ & 69 & Desirable & 2011 (June) \\
\hline Bastrop, TX ${ }^{\mathrm{e}}$ & TX-B & 6 & $93(86)$ & $30^{\circ} 03.554^{\prime} \mathrm{N} / 97^{\circ} 18.402^{\prime} \mathrm{W}$ & 123 & Wichita & 2012 (June) \\
\hline Carlyle, $\mathrm{IL}^{\mathrm{e}}$ & IL-C & 6 & $53(48)$ & $38^{\circ} 29.323^{\prime} \mathrm{N} / 89^{\circ} 30.212^{\prime} \mathrm{W}$ & 143 & Native seedling & 2012 (June) \\
\hline Total & $\ldots$ & 63 & $784(739)$ & $\ldots$ & $\ldots$ & $\ldots$ & $\ldots$ \\
\hline
\end{tabular}


the MAT1-2 locus. The draft genome sequence of $V$. effusa isolate TxPawnee1-1 was sequenced at the University of Kentucky, HealthCare Genomics Core Laboratory, using an Illumina MiSeq. The sequencing library was prepared using the Nextera XT DNA library kit (Illumina) producing, in total, 33,616,218 paired-end reads, with an average length of $160 \mathrm{bp}$. The genome was assembled using CLC Genomics Workbench 8.5.1 and all scaffold sequences at least $500 \mathrm{bp}$ in length were included in the final assembly. The final genome size was $35.5 \mathrm{Mb}$, represented by 2,469 scaffolds. The N50 is $83.3 \mathrm{~kb}$ and the smallest and largest contigs are 2.5 and $456 \mathrm{~kb}$, respectively.

The $V$. inaequalis MAT genes, flanking genes, and a reference gene encoding $\beta$-tubulin (TUB2) (M97951) were used as queries (gene and encoded protein for each) against the $V$. effusa genomes with custom BLAST searches using SequenceServer (Altschul et al. 1990; Priyam et al. 2015). Once contigs containing these genes were identified, each gene was predicted using FGENESH with Leptosphaeria spp. as the training set (Solovyev et al. 2006), with additional manual editing based on the prediction of conserved introns between $V$. effusa and $V$. inaequalis. Each MAT locus was annotated using Geneious v10.0.6 (Biomatters Ltd., Auckland, New Zealand) and MacVector v13.5.5 (MacVector, Inc., Apex, NC), and comparisons of each MAT idiomorph were performed using Dot Plot in MacVector. Protein domains were identified with InterProScan 5 (Jones et al. 2014). The GenBank accession numbers for $V$. effusa MAT1-1, MAT1-2, and TUB2 sequences are MF167363 to MF167376, MF173107, and MF173108, respectively.

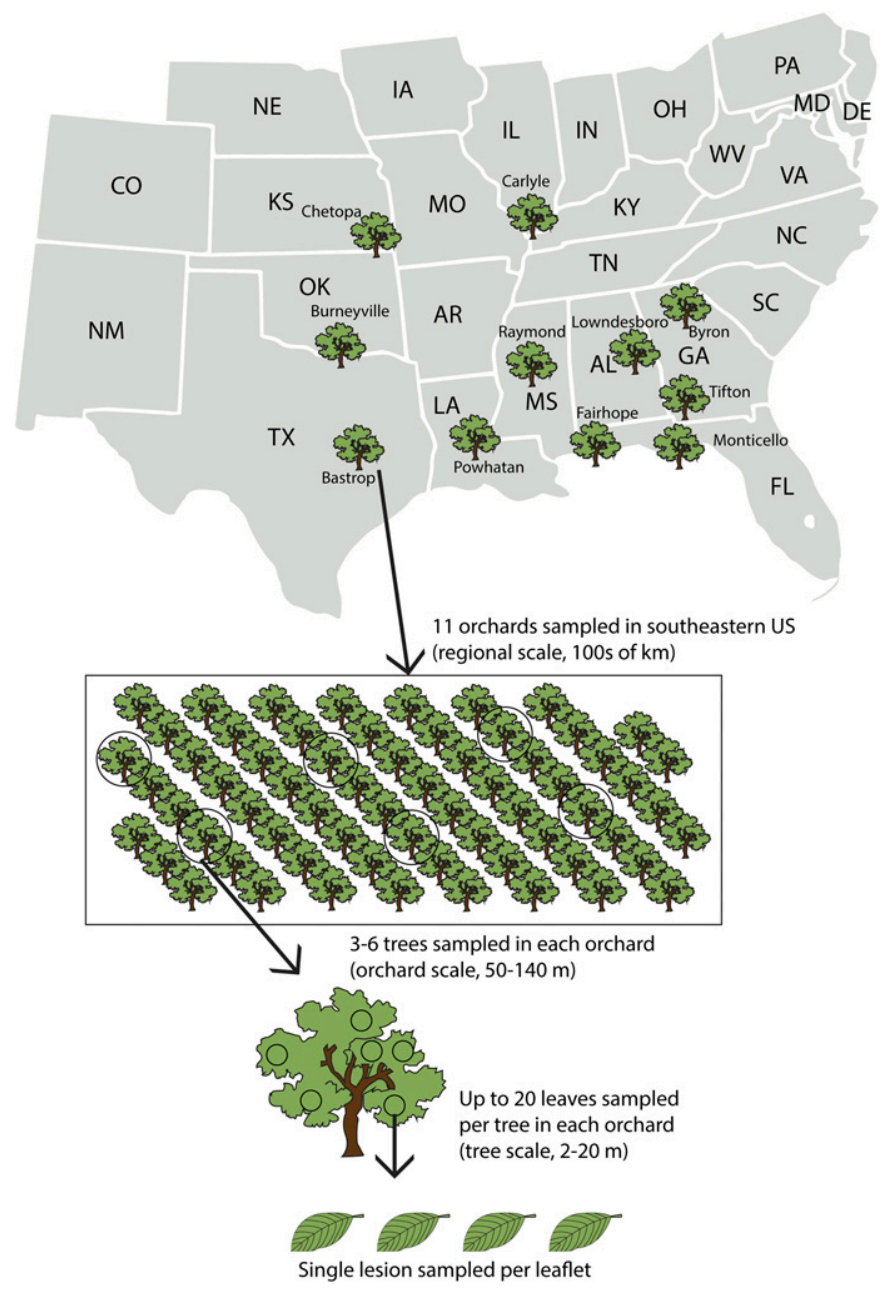

Fig. 1. Sampling strategy for isolates of Venturia effusa from pecan trees in orchards in the southeastern United States. Reprinted from Bock et al. (2017b).
PCR of the $M A T$ region. PCR conditions with individual primer sets for $M A T$ or flanking genes (Table 2) were initially established using DNA from a subset of 14 isolates representing six states and six cultivars. The multiplex PCR was established with primer sets for MAT1-1-1, MAT1-2-1, and TUB2 (Table 2) with the same samples prior to screening the hierarchical collection of 784 isolates. PCR was performed in a total volume of $25 \mu$ l containing $3 \mathrm{ng}$ of genomic DNA, 1.0 U of GoTaq DNA Polymerase (Promega Corp., Madison, WI), $1 \times$ Green GoTaq Reaction Buffer containing $1.5 \mathrm{mM} \mathrm{MgCl} 2,0.2 \mathrm{mM}$ each dNTP (Promega Corp.), and $1 \mu \mathrm{M}$ target-specific primers (Table 2). The cycling parameters were $94^{\circ} \mathrm{C}$ for $1 \mathrm{~min}$; then, 30 cycles of $94^{\circ} \mathrm{C}$ for $15 \mathrm{~s}, 60^{\circ} \mathrm{C}$ for $30 \mathrm{~s}$, and $72^{\circ} \mathrm{C}$ for $45 \mathrm{~s}$; followed by $72^{\circ} \mathrm{C}$ for $10 \mathrm{~min}$. Multiplex and singletarget PCR used the same reaction and cycling conditions.

The region ( $7.8 \mathrm{~kb}$ ) spanning the MAT locus between the flanking genes was amplified using Promega GoTaq Long PCR master mix (Promega Corp.). PCR was performed in a total volume of $50 \mu \mathrm{l}$ containing 100 ng of DNA, GoTaq Long DNA Polymerase (Promega Corp.), and $1 \mu \mathrm{M}$ target-specific primers (dnaL-F1 and PHdom-R) (Table 2). The cycling parameters were $94^{\circ} \mathrm{C}$ for $2 \mathrm{~min}$; followed by 30 cycles of $94^{\circ} \mathrm{C}$ for $15 \mathrm{~s}, 56^{\circ} \mathrm{C}$ for $30 \mathrm{~s}$, and $72^{\circ} \mathrm{C}$ for $8 \mathrm{~min}$; followed by $72^{\circ} \mathrm{C}$ for $10 \mathrm{~min}$. Idiomorph-specific primers (Supplementary Table S1) were designed to complete sequencing across the entire 8-kb amplicon from each isolate.

All amplicons were analyzed by gel electrophoresis using either 1.5 or $0.8 \%$ agarose gel in $1 \times$ Tris-borate-EDTA buffer and visualized with ethidium bromide by UV transillumination. When necessary, PCR products were purified with the QIAquick PCR Purification Kit (Qiagen Inc., Valencia, CA) and sequenced with Big Dye Terminator Chemistry (version 3.1; Applied Biosystems, Foster City, CA) using a 3730 DNA analyzer (Thermo-Fisher Scientific, Grand Island, NY). MAT loci sequence data generated from each $V$. effusa isolate by Sanger sequencing was assembled using Sequencher DNA sequence analysis software (v5.1; Gene Codes Corporation, Ann Arbor, MI) and evaluated with Geneious and MacVector.

SSR genotyping. Clonality of each isolate (apart from TxPawnee11 and TxPawnee1-2) was previously determined by Bock et al. (2017b) using 30 microsatellite markers known to be reliable for genotyping $V$. effusa (Bock et al. 2016a). The primers and conditions used for the reactions were described by Bock et al. (2016a, 2017b). Briefly, the reaction volume $(5 \mu \mathrm{l})$ contained $1.5 \mu \mathrm{l}$ of template DNA (1.5 to $2.0 \mathrm{ng}$ ), $0.25 \mu \mathrm{l}$ of primer, $0.75 \mu \mathrm{l}$ of distilled $\mathrm{H}_{2} \mathrm{O}$, and $2.5 \mu \mathrm{l}$ of PCR Master Mix (2x) (Promega Corp.). The cycling conditions consisted of an initial denaturation at $94^{\circ} \mathrm{C}$ for $1 \mathrm{~min}$; followed by 33 cycles of $94^{\circ} \mathrm{C}$ for $40 \mathrm{~s}, 58^{\circ} \mathrm{C}$ for $40 \mathrm{~s}$, and $72^{\circ} \mathrm{C}$ for $20 \mathrm{~s}$; and a final primer extension

TABLE 2. Primer combinations used to detect the mating type (MAT) loci of Venturia effusa ${ }^{\mathrm{a}}$

\begin{tabular}{|c|c|c|c|}
\hline Target & $\begin{array}{c}\text { Primer } \\
\text { name }\end{array}$ & Sequence $5^{\prime} \rightarrow 3^{\prime}$ & $\begin{array}{l}\text { Product } \\
\text { size (bp) }\end{array}$ \\
\hline \multirow[t]{2}{*}{ MAT1-1-1 ${ }^{\mathrm{b}}$} & MTA-F & ATCACACTTGCCGCCAAGCGACC & 242 \\
\hline & MTA-R & TTGATGAGAGGGCAGACGAT & \\
\hline \multirow[t]{2}{*}{$M A T 1-2-1^{\mathrm{b}}$} & MTB-F1 & AAGGTTCCTCGCCCAGCCAATG & 775 \\
\hline & MTB-R2 & CTAAAGTTGGAAGAGAGGTTGG & \\
\hline \multirow[t]{2}{*}{$T U B 2^{\mathrm{b}}$} & tubB-F & TCCATCTTCAGACTGGCCAATG & 517 \\
\hline & tubB-R & CGGTGTAGTGTCCTTTGGCCCA & \\
\hline \multirow[t]{2}{*}{$A P N 2^{\mathrm{c}}$} & dnaL-F & GAGCAGAAGATCAATGCGAGAC & 365 \\
\hline & dnaL-R & AACATGTCTTTGATACTCCTTC & \\
\hline \multirow[t]{2}{*}{ hypo ${ }^{c}$} & PHdom-F & ATGGTGACTTTCACCGCTTTCCT & 387 \\
\hline & PHdom-R & GAAGATGCTCCTGTACATGCTCTG & \\
\hline \multirow{2}{*}{$\begin{array}{l}\text { MAT } \\
\text { locus }\end{array}$} & dnaL-F1 & GAAGAATGGACCAAGCTCTTCAC & 7,886 \\
\hline & PHdom-R & GAAGATGCTCCTGTACATGCTCTG & \\
\hline \multicolumn{4}{|c|}{$\begin{array}{l}\text { a Primers were designed to coding regions of } V \text {. effusa genes (GenBank ac } \\
\text { cession numbers MF167363 to MF167376 and MF173107) identified in thi } \\
\text { study and tested against } 14 \text { different isolates. } \\
\text { b Primers used for multiplex polymerase chain reaction to differentiate isolat } \\
\text { mating type. } \\
\text { c Genes flanking the MAT genes. }\end{array}$} \\
\hline
\end{tabular}


step at $72^{\circ} \mathrm{C}$ for $30 \mathrm{~min}$. Forward primers were labeled with either FAM, NED, HEX, or PET dye. All marker primer combinations were run on a Hitachi 3500 Genetic Analyzer (Thermo-Fisher Scientific). The resulting peaks were analyzed and scored by base pair size for
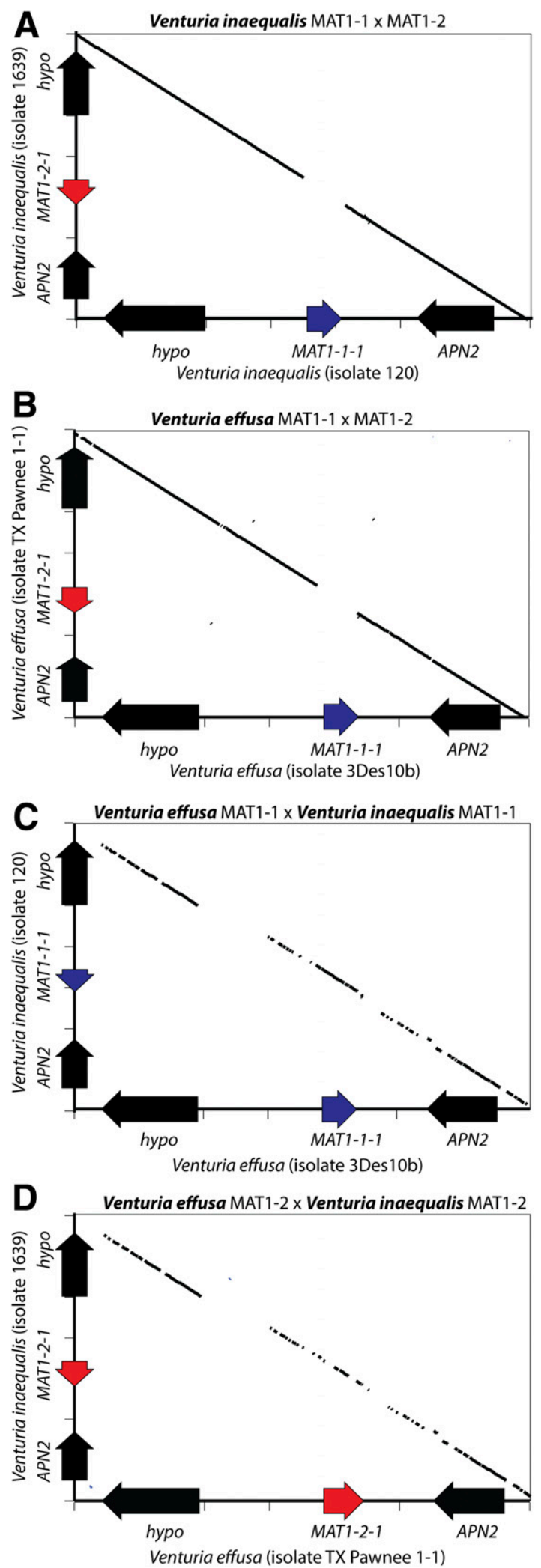

Fig. 2. Synteny across the mating type $(M A T)$ locus between isolates of Venturia effusa and $V$. inaequalis. Comparison of A, V. inaequalis MAT1-1 and MAT1-2; B, V. effusa MAT1-1 and MAT1-2; C, V. effusa MAT1-1 and V. inaequalis MAT1-1; and D, V. effusa MAT1-2 and V. inaequalis MAT1-2. Dot plots show conserved regions based on a window size of 30 nucleotides with $60 \%$ identity. each marker using GeneMarker (SoftGenetics, State College, PA). $V$. effusa is a haploid organism and, thus, only a single band was observed at each locus for each isolate.

Statistics. The isolates of $V$. effusa were pooled depending on the hierarchy of spatial scales to determine MAT distribution on leaflets in trees, trees within orchards, and throughout the region. Due to clonality potentially biasing the analysis, the analyses were performed on both clone-corrected and non-clone-corrected data sets (Bock et al. 2017b). The clonal correction was adjusted specifically for the hierarchical scale being studied, such that all populations analyzed contained only a single copy of each genotype based on the microsatellite multilocus haplotype. The clones were identified using GenAlex (Peakall and Smouse 2006, 2012), and all analyses were performed using SAS (v9.4; SAS Institute, Cary,

A verst

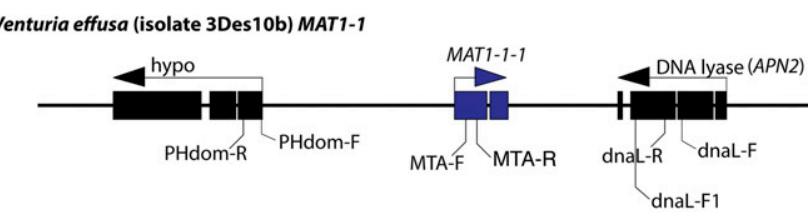

Venturia effusa (isolate TX Pawnee 1-1) MAT1-2

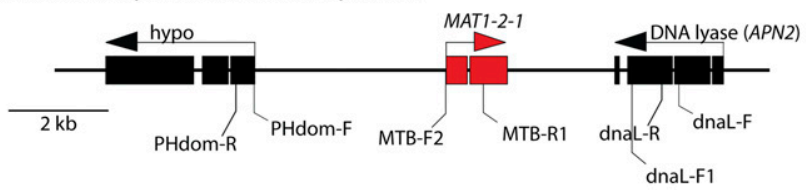

B
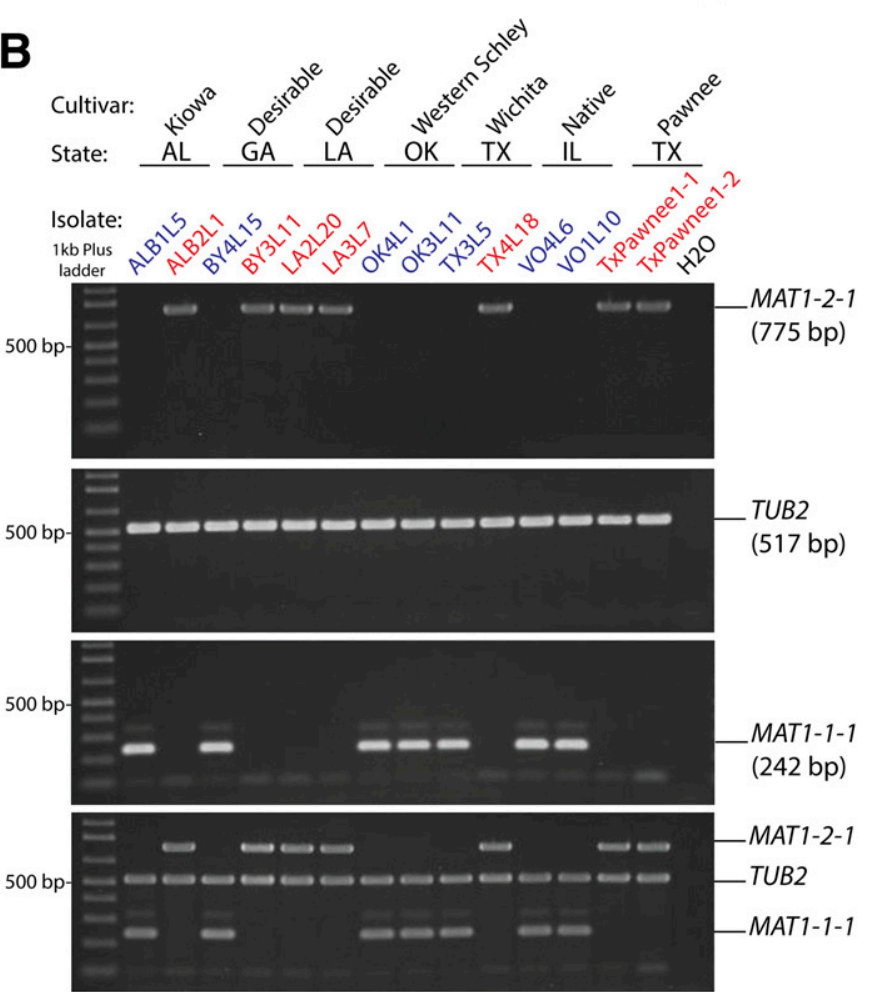

Fig. 3. Venturia effusa mating type (MAT) locus and multiplex polymerase chain reaction (PCR) screen. A, Gene organization of each MAT locus of $V$. effusa. Each gene is represented by an arrow showing the direction of transcription over boxes that represent exons of the coding sequence. Primer locations are shown as lines below the sequence. PHdom-R and dnaL-F1 were used to amplify the complete MAT locus from the subset of 14 isolates. Each MAT locus is drawn to scale. B, Amplicons resulting from a PCR screen to determine the mating type of $V$. effusa isolates. The top three gels show PCR amplification products using single primer sets for MAT1-2-1 (primers MTBF1 and MTB-R2), TUB2 (primers tubB-F and tubB-R), and MAT1-1-1 (primers MTA-F and MTA-R). The bottom gel shows the results of the multiplex PCR when all three primer sets are combined. Faint nonspecific shadow bands are seen with the MAT1-1-1 primer set. 
NC). The proportion of MAT1-1 and MAT1-2 isolates present in populations at different spatial scales (the region, within orchards, and within individual trees) was tested for equilibrium (the null hypothesis of a 1:1 ratio). For each analysis, a $\chi^{2}$ test was used to determine whether the proportions departed significantly from the 1:1 ratio (Everitt 1992). Furthermore, additional contingency table $\chi^{2}$ analyses were performed at the spatial scales of the region and orchard to determine whether individual subpopulations (orchards or trees) within the larger spatial scale (region or orchard, respectively) differed in MAT frequencies. Due to the limitations of the $\chi^{2}$ test when analyzing small sample sizes (generally, populations with expected values $<5$ ), an exact binomial test (two-tailed) for goodness-of-fit was used to determine whether observed MAT frequencies within populations deviated from the 1:1 ratio.

Population genetic and gene diversity was analyzed for each $M A T$ component (MAT1-1 and MAT1-2) of the population at the region and orchard scales. Analyses were based on the haploid multilocus genotypes (MLG) and microsatellite allele presence and frequency in the populations described previously (Bock et al. 2017b). Analyses were performed using the R (v3.4.1) (R Core Team, 2012) package poppr (Kamvar et al. 2014) for all isolates and the clonecorrected data. The number of MLG observed and the clonecorrected number of MLG were calculated; expected MLG (eMLG), which approximates the number of genotypes (genotypic richness) that would be expected at the largest, shared sample size based on rarefaction (Grünwald et al. 2003), was also calculated. Genotypic diversity, which measures both genotypic richness and abundance, was measured using the Shannon-Wiener index of MLG diversity (Shannon 2001), Stoddart and Taylor's index of MLG diversity (Stoddart and Taylor 1988), and Simpson's index $(\lambda)$ (Simpson 1949). Genotype evenness was measured as E0.5 (Grünwald et al. 2003; Ludwig and Reynolds 1988; Pielou 1975), and Nei's unbiased gene diversity was calculated $\left(\mathrm{H}_{\mathrm{exp}}\right)(\mathrm{Nei} 1978)$.

\section{RESULTS}

Identification and arrangement of the MAT loci. The $M A T$ idiomorphs from two races of the closely related species $V$. inaequalis (Fig. 2A) were used as query sequences to search the available genome of $V$. effusa. Each MAT locus of $V$. inaequalis contained either a MAT1-1-1 or MAT1-2-1 gene that was flanked by conserved genes encoding a DNA lyase (APN2) and a hypothetical protein with sequence similarity to a Pleckstrin homology (PH) domain-containing protein (Fig. 2A). BLASTn and tBLASTn searches using these four gene and protein sequences of $V$. inaequalis, respectively, matched a region on a single contig (contig 00032) in the genome sequence of $V$. effusa (isolate 3Des 10b) that contained MAT1-1-1 and the two flanking genes (Fig. $3 \mathrm{~A})$. Pairwise comparison of the $14-\mathrm{kb}$ region encompassing the MAT1-1 idiomorph from $V$. effusa 3Des10b and V. inaequalis confirmed synteny across the MAT locus, which showed that V. inaequalis and V. effusa have the same gene organization (Fig. 2). The MAT1-1-1 gene is predicted to contain a 61-bp intron and encode a 335 -amino-acid protein that shares $74 \%$ identity $(84 \%$ similarity) with the $V$. inaequalis ortholog.

PCR used to test for the presence of MAT1-1-1 (primers MTA$\mathrm{F}$ and MTA-R) from a subset of 14 isolates of $V$. effusa representing different locations and cultivars resulted in amplification of a specific band in seven of these isolates (Fig. 3B). However, we were able to amplify the two flanking genes from all 14 isolates using primer sets dnaL-F/dnaLR and PHdom-F/PHdom-R (data not shown). This result indicated that the remaining isolates likely represented the opposite mating type. Long-range PCR was used to amplify each MAT locus with primers, dnaL-F1 and PHdom-R, designed to the conserved flanking genes, which resulted in the amplification of a 7.8-kb fragment from each isolate. Sequence analyses using BLASTn and tBLASTn with the $M A T$ genes and protein sequences of $V$. inaequalis, respectively, confirmed that of the 14 isolates, seven contained a sequence homologous to MAT1-1-1 and the remaining seven showed similarity to MAT1-2-1.

The MAT1-2-1 gene of V. effusa is predicted to encode a 390amino-acid protein. Similar to other MAT1-2-1 genes is the placement of an intron located in the region encoding the HMG domain (Debuchy and Turgeon 2006). The predicted protein of the MAT1-2-1 gene of $V$. effusa shares $59 \%$ identity and $71 \%$ similarity to the MAT1-2-1 gene of $V$. inaequalis, with the greatest identity across the region containing the HMG domain. A draft genome generated from V. effusa TxPawnee1-1 using NextGen sequencing was used to complete the gene sequences flanking MAT1-2-1 (Fig. 3A). The MAT1-2 locus was located on a 121.3-kb contig. Pairwise comparisons of $V$. effusa MAT1-2 show gene organization similar to $V$. inaequalis MAT1-2 and only varied at the location of each MAT gene with V. effusa isolate 3Des10b (Fig. 2).

TABLE 3. Mating type (MAT) frequencies of Venturia effusa in populations from pecan orchards in different locations in the southeastern United States

\begin{tabular}{|c|c|c|c|c|c|c|c|c|}
\hline \multirow[b]{2}{*}{ Pop $^{\mathrm{a}}$} & \multicolumn{4}{|c|}{ Clone corrected } & \multicolumn{4}{|c|}{ Nonclone corrected } \\
\hline & $M A T 1-1 / M A T 1-2(n)$ & $\chi^{2}(P)^{\mathrm{b}}$ & $P^{\mathrm{c}}$ & $\chi^{2}(P)^{\mathrm{d}}$ & MAT1-1/MAT1-2 (n) & $\chi^{2}(P)^{\mathrm{b}}$ & $P^{\mathrm{c}}$ & $\chi^{2}(P)^{\mathrm{d}}$ \\
\hline AL-F & $47: 45$ & $0.1(0.8)$ & 0.9 & $0.6(1.0)_{5}$ & $48: 45$ & $0.1(0.8)$ & 0.8 & $0.7(0.9)_{5}$ \\
\hline AL-L & $41: 42$ & $0.0(0.9)$ & 1 & $4.2(0.5)_{5}$ & $46: 45$ & $0.01(0.9)$ & 1 & $5.8(0.3)_{5}$ \\
\hline GA-B & $19: 40$ & $7.5(0.006)^{* *}$ & $0.009 * *$ & $7.7(0.2)_{5}$ & $19: 44$ & $9.9(0.002)^{* * *}$ & $0.002 * *$ & $8.7(0.1)_{5}$ \\
\hline KS-C & $14: 19$ & $0.8(0.4)$ & 0.5 & $0.2(0.9)_{3}$ & $14: 20$ & $1.1(0.3)$ & 0.4 & $0.1(1.0)_{2}$ \\
\hline LA-P & $28: 38$ & $1.5(0.2)$ & 0.3 & $3.3(0.7)_{5}$ & $28: 40$ & $2.1(0.2)$ & 0.2 & $3.6(0.6)_{5}$ \\
\hline MS-R & $43: 37$ & $0.5(0.5)$ & 0.6 & $8.1(0.2)_{5}$ & $47: 42$ & $0.3(0.6)$ & 0.7 & $7.9(0.2)_{5}$ \\
\hline FL-M & $29: 21$ & $1.3(0.3)$ & 0.3 & $9.1(0.1)_{5}$ & $30: 22$ & $1.2(0.3)$ & 0.3 & $9.4(0.09)_{5}$ \\
\hline OK-B & $45: 55$ & $1.0(0.3)$ & 0.4 & $4.1(0.5)_{5}$ & $46: 57$ & $1.2(0.3)$ & 0.3 & $3.6(0.6)_{5}$ \\
\hline GA-T & $28: 16$ & $3.3(0.07)$ & 0.1 & $4.7(0.5)_{5}$ & $29: 16$ & $3.8(0.05)^{*}$ & 0.07 & $5.1(0.4)_{5}$ \\
\hline TX-B & $35: 51$ & $3.0(0.09)$ & 0.1 & $9.3(0.1)_{5}$ & $38: 55$ & $3.1(0.08)$ & 0.1 & $9.7(0.09)_{5}$ \\
\hline IL-C & $26: 22$ & $0.3(0.6)$ & 0.7 & $8.2(0.2)_{5}$ & $29: 24$ & $0.5(0.5)$ & 0.6 & $9.2(0.1)_{5}$ \\
\hline Total & $355: 384$ & $1.1(0.3)$ & 0.3 & $17.9(0.06)_{10}$ & $374: 410$ & $1.65(0.2)$ & 0.2 & $21.6(0.02)_{10} *$ \\
\hline
\end{tabular}

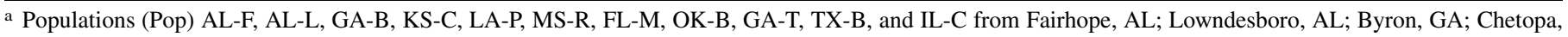
KS; Powhatan, LA; Raymond, MS; Monticello, FL; Burneyville, OK; Tifton, GA; Bastrop, TX; and Carlyle, IL, respectively.

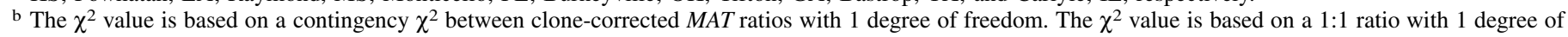
freedom for the clone-corrected sample; the $P$ value in parentheses and an asterisk $(*)$ indicates that the $M A T$ frequencies were significantly different from $1: 1(* *$ indicates $P<0.01)$.

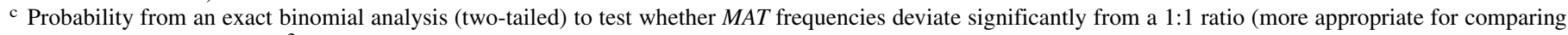
small populations than a $\chi^{2}$ test).

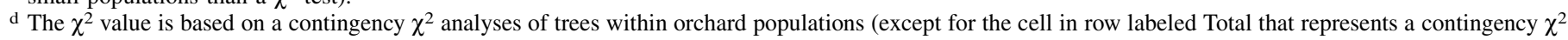
analyses among orchard populations). Subscript indicates degrees of freedom; the $P$ value in parentheses indicates probability that the $M A T$ frequencies differ significantly from $1: 1$. 
Six single-nucleotide polymorphisms (SNP) were identified within the MAT1-1-1 gene across the seven MAT1-1 isolates, of which three SNP resulted in nonsynonymous changes to the encoded sequence. Four SNP were identified within the MAT1-2-1 gene across the seven MAT1-2 isolates, which resulted in three nonsynonymous changes to the encoded sequence. Pairwise comparison of each $V$. effusa MAT locus within a single mating type revealed nucleotide sequence identity ranging from 94.7 to $97.1 \%$ for all the MAT1-1 isolates and 93.7 to $100 \%$ for the MAT1-2 isolates. Only the two TxPawnee isolates, isolated from the same fruit, had identical MAT loci. Sequence similarity of the MAT locus between $V$. effusa MAT1-1 and MAT1-2 isolates, excluding the MAT gene, ranged from 90.4 to $96.6 \%$.

Development of a multiplex PCR screen to detect mating type. A PCR screen was developed to identify mating type and determine whether the MAT genes were present in equilibrium within populations of $V$. effusa. Primers specific for MAT1-1-1, MAT1-2-1, and TUB2 were established as a multiplex PCR. The amplicons for each mating type were differentiated based on size (the amplicon sizes for MAT1-1-1 and MAT1-2-1are 242 and $775 \mathrm{bp}$, respectively), and the presence of the reference gene (TUB2, a 517-bp amplicon) provided confirmation of the genomic DNA quality (Fig. 3B). The primer combinations were tested on 14 isolates as individual primer sets and within a multiplex PCR, which resulted in amplification that was consistent with the $M A T$ sequence data (Fig. 3B).

The hierarchical collection of isolates of V. effusa $(n=784)$ was tested for mating type using the multiplex PCR. Nearly all samples amplified a specific single MAT gene. However, a very low percentage of samples $(1.5 \%, n=12$ isolates $)$ initially amplified both MAT bands, although this was resolved when DNA was reisolated from a monoconidial culture. In total, we obtained confirmation of mating type for all 784 isolates. The total number of isolates included in this study after clone correction was reduced to 739 (Table 1).

Mating type frequencies at different spatial scales. Clone correction had a small effect on isolate counts in the different populations (Table 3). The clone-corrected data showed that, at the largest spatial scale (the whole southeastern region population), there was no detectable disequilibrium between the two mating types $\left(M A T 1-1-1 / M A T 1-2-1\right.$ ratio $=48: 52 \%, \chi^{2}=1.1[P=0.3]$; exact binomial test, $P=0.3$ ) (Table 3). However, at the orchard scale, there was 1 population (GA-B, Desirable cultivar) out of the 11 that departed from equilibrium $\left(32: 68 \%\right.$ ratio, $\chi^{2}=7.5[P=$ $0.006]$; exact binomial test, $P=0.009$ ) (Table 3 ). In contrast, the orchard-scale data that were not clone-corrected had two populations (GA-B and GA-T) that deviated from a 1:1 MATratio based on the $\chi^{2}$ test (Table 3 ), demonstrating the impact of clones on the analysis. However, the exact binomial test showed only one of these populations (GA-B) to have mating types present at frequencies different from $1: 1$. The contingency $\chi^{2}$ test comparing MAT ratios among orchards based on the clone-corrected data in the southeast indicated no differences $\left(\chi^{2}=17.9[P=0.06]\right)$ (Table 3$)$. The contingency $\chi^{2}$ test comparing MAT ratios on trees within each of the orchards also detected no difference in the $M A T$ frequencies among individual trees within orchards $\left(\chi^{2}=0.2\right.$ to $9.3[P=0.1$ to $0.9]$ ) (Table 3). There was also no apparent effect of host cultivar on the frequency of mating types. The 11 populations are represented by four cultivars: Desirable (6 populations), Kiowa (1 population), Wichita (1 population), and Western Schley (1 population), plus two

TABLE 4. Mating type (MAT) frequencies of Venturia effusa in populations from individual pecan trees that deviated from 1:1 equilibrium in orchards in different locations in the southeastern United States ${ }^{\mathrm{a}}$

\begin{tabular}{|c|c|c|c|c|c|c|}
\hline \multirow[b]{2}{*}{ Pop, tree ${ }^{b}$} & \multicolumn{3}{|c|}{ Clone corrected } & \multicolumn{3}{|c|}{ Nonclone corrected } \\
\hline & MAT1-1: MAT1-2(n) & $\chi^{2}(P)^{\mathrm{c}}$ & $P^{\mathrm{d}}$ & MAT1-1: MAT1-2(n) & $\chi^{2}(P)^{\mathrm{c}}$ & $P^{\mathrm{d}}$ \\
\hline \multicolumn{7}{|l|}{ GA-B } \\
\hline 2 & $5: 7$ & $0.3(0.6)$ & 0.8 & $5: 7$ & $0.3(0.6)$ & 0.8 \\
\hline 3 & 1:10 & $7.4(0.007)^{* * *}$ & $0.01 * *$ & 1:12 & $9.3(0.002) * *$ & $0.003 * *$ \\
\hline 4 & $3: 4$ & $0.1(0.7)$ & 1 & $3: 4$ & $0.1(0.7)$ & 1 \\
\hline 5 & $4: 2$ & $0.7(0.4)$ & 0.7 & $4: 2$ & $0.7(0.4)$ & 0.7 \\
\hline 1 & $6: 8$ & $0.3(0.6)$ & 0.8 & $6: 9$ & $0.6(0.4)$ & 0.6 \\
\hline 2 & $5: 6$ & $0.1(0.8)$ & 1 & $7: 7$ & $0.0(1.0)$ & 1 \\
\hline 3 & $12: 4$ & $4.0(0.05)^{*}$ & 0.08 & $12: 4$ & $4.0(0.05)^{*}$ & 0.08 \\
\hline 4 & $4: 7$ & $0.8(0.4)$ & 0.6 & $5: 7$ & $0.3(0.6)$ & 0.8 \\
\hline 5 & $10: 4$ & $2.6(0.1)$ & 0.2 & $11: 5$ & $2.3(0.1)$ & 0.2 \\
\hline 6 & $6: 9$ & $0.6(0.4)$ & 0.6 & $6: 10$ & $1.0(0.3)$ & 0.5 \\
\hline \multicolumn{7}{|l|}{ FL-M } \\
\hline 6 & $3: 1$ & $1.0(0.3)$ & 0.6 & $3: 1$ & $1.0(0.3)$ & 0.6 \\
\hline \multicolumn{7}{|l|}{ TX-B } \\
\hline 1 & $12: 6$ & $2.0(0.2)$ & 0.2 & $12: 6$ & $2.0(0.2)$ & 0.2 \\
\hline 2 & $3: 13$ & $6.3(0.01)^{* *}$ & $0.02 *$ & $3: 13$ & $6.3(0.01)^{* *}$ & $0.02 *$ \\
\hline 3 & $5: 8$ & $0.7(0.4)$ & 0.6 & $6: 9$ & $0.6(0.4)$ & 0.6 \\
\hline 4 & $3: 8$ & $2.3(0.1)$ & 0.2 & $4: 11$ & $3.3(0.07)$ & 0.1 \\
\hline 5 & $7: 8$ & $0.1(0.8)$ & 1 & $7: 8$ & $0.1(0.8)$ & 1 \\
\hline 6 & $5: 8$ & $0.7(0.4)$ & 0.6 & $6: 8$ & $0.3(0.6)$ & 0.8 \\
\hline
\end{tabular}

a Data in bold indicate tree populations that deviate from equilibrium of mating types.

b Populations (Pop) GA-B, MS-R, FL-M, and TX-B from Byron, GA; Raymond, MS; Monticello, FL; and Bastrop, TX, respectively.

c The $\chi^{2}$ value is based on a contingency $\chi^{2}$ between clone-corrected MAT ratios with 1 degree of freedom. The $\chi^{2}$ value is based on a 1:1 ratio with 1 degree of freedom for the clone-corrected sample; the $P$ value in parentheses and the asterisk (*) indicates MAT frequencies significantly different from 1:1 (* and ** indicate $P<0.05$ and 0.01 , respectively).

d Probability from an exact binomial analysis (two-tailed) to test whether MAT frequencies deviate significantly from a 1:1 ratio (more appropriate for comparing small populations than a $\chi^{2}$ test). 
populations of native trees. The only population that departed from equilibrium was a Desirable population from GA-B (Table 3).

Although isolate numbers were small in several cases, only 4 tree populations in three orchards (GA-B tree 1 and 3, MS-R tree 3, and TX-B tree 2) of the 63 tree populations sampled deviated from $M A T$ equilibrium based on the $\chi^{2}$ test (6.3\% of trees) (Table 4 ; Supplementary Table S2). When based on the exact test of equilibrium, only three tree populations in three orchards (GA-B tree 3, FL-M tree 5, and TX-B tree 2) deviated from a 1:1 ratio (4.8\%), indicating that the populations in individual trees were generally in equilibrium. Analysis of the non-clone-corrected data suggested little effect of clone correction at the spatial scale of the tree (Table 4).

Genetic and gene diversity in relation to mating type at different spatial scales. The number of MLG ranged from 14 (KS-C, MAT1-1) and 19 (KS-C, MAT1-2) to 45 (OK-B, MAT1-1) and 55 (OK-B, MAT1-2). However, the eMLG value indicated that both mating types in all populations had the same expected number of genotypes (14) at the largest, shared sample size based on rarefaction (Table 5). Shannon-Weiner's (2.64 to 3.93), Stoddart and Taylor's (14 to 55), and Simpson's (0.929 to 0.982) indices of diversity all demonstrated that genetic diversity was similar regardless of whether they were MAT1-1 or MAT1-2 in all orchard populations (Table 5). Not unexpectedly, the magnitude of the indices showed some relationship to sample size (for example, the GA-B MAT1-1 population had only 19 isolates and ShannonWeiner's index was 2.94, compared with 3.74 for MAT1-1, which comprised 42 isolates) (Grünwald et al. 2003). Other populations where there was either a small sample size or a difference in sample size for isolates of MAT1-1 and MAT1-2 included orchards KS-C and GA-T. Otherwise, the populations of the two MAT idiomorphs had similar magnitudes of genetic diversity. Due to the number of isolates, measures of diversity for both mating types were greatest (yet similar to each other) at the scale of the region (ShannonWeiner's index $=5.85$ and 5.92 for MAT1-1 and MAT1-2, respectively). Evenness was very high in all populations, based on both all data and the clone-corrected data, regardless of mating type (clonality was low). Nei's unbiased measure of gene diversity was similar for each population regardless of MAT idiomorph, and was also highest at the regional scale.

\section{DISCUSSION}

The recent genome sequencing efforts invested in V. effusa (Bock et al. 2016b) and the closely related heterothallic sexual species, $V$. inaequalis (Deng et al. 2017), provided an opportunity to compare $M A T$ loci across each of these pathogens. Two MAT idiomorphs were identified within the genome sequences, with each isolate containing a single idiomorph. The sequence information enabled us to develop a PCR assay to screen a large collection of isolates, where we determined that the MAT idiomorphs were present in equilibrium in populations of $V$. effusa, a characteristic often typical of sexually recombining heterothallic species. Until now, $V$. effusa has been considered strictly an asexual pathogen that can rapidly spread to epidemic levels on pecan throughout the growing season due to its

TABLE 5. Statistics summarizing the genetic diversity of populations of Venturia effusa in relation to mating type (MAT) idiomorph in the southeastern United States

\begin{tabular}{|c|c|c|c|c|c|c|c|c|c|c|c|c|}
\hline \multirow[b]{2}{*}{ Pop $^{\mathrm{a}}$} & \multirow[b]{2}{*}{ MAT } & \multirow[b]{2}{*}{$M_{L G}{ }^{b}$} & \multirow[b]{2}{*}{$\mathrm{eMLG}^{\mathrm{c}}$} & \multicolumn{4}{|c|}{ Clone corrected } & \multicolumn{5}{|c|}{ Nonclone corrected } \\
\hline & & & & $\mathrm{SW}^{\mathrm{d}}$ & $\mathrm{ST}^{\mathrm{e}}$ & $\mathrm{SI}^{\mathrm{f}}$ & $\mathrm{Nei}^{\mathrm{g}}$ & $\mathrm{SW}^{\mathrm{d}}$ & $\mathrm{ST}^{\mathrm{e}}$ & $\mathrm{SI}^{\mathrm{f}}$ & E. $5^{\mathrm{h}}$ & $\mathrm{Nei}^{\mathrm{g}}$ \\
\hline \multirow[t]{2}{*}{ AL-F } & MAT1-1 & 47 & 14 & 3.85 & 47 & 0.979 & 0.58 & 3.84 & 46.1 & 0.978 & 0.988 & 0.579 \\
\hline & MAT1-2 & 45 & 14 & 3.81 & 45 & 0.978 & 0.609 & 3.81 & 45 & 0.978 & 1 & 0.609 \\
\hline AL-L & MAT1-2 & 42 & 14 & 3.74 & 42 & 0.976 & 0.651 & 3.71 & 39.7 & 0.975 & 0.967 & 0.65 \\
\hline \multirow[t]{2}{*}{ GA-B } & MAT1-1 & 19 & 14 & 2.94 & 19 & 0.947 & 0.578 & 2.94 & 19 & 0.947 & 1 & 0.578 \\
\hline & MAT1-2 & 40 & 14 & 3.69 & 40 & 0.975 & 0.549 & 3.63 & 33.4 & 0.97 & 0.885 & 0.547 \\
\hline LA-P & MAT1-2 & 38 & 14 & 3.64 & 38 & 0.974 & 0.505 & 3.62 & 36.4 & 0.973 & 0.974 & 0.512 \\
\hline \multirow[t]{2}{*}{ MS-R } & MAT1-1 & 43 & 14 & 3.76 & 43 & 0.977 & 0.598 & 3.72 & 38.8 & 0.974 & 0.937 & 0.593 \\
\hline & MAT1-2 & 37 & 14 & 3.61 & 37 & 0.973 & 0.581 & 3.61 & 35.3 & 0.972 & 0.957 & 0.582 \\
\hline \multirow[t]{2}{*}{ FL-M } & MAT1-1 & 29 & 14 & 3.37 & 29 & 0.966 & 0.58 & 3.35 & 28.1 & 0.964 & 0.981 & 0.578 \\
\hline & MAT1-2 & 21 & 14 & 3.04 & 21 & 0.952 & 0.57 & 3.03 & 20.2 & 0.95 & 0.975 & 0.557 \\
\hline OK-B & MAT1-1 & 45 & 14 & 3.81 & 45 & 0.978 & 0.686 & 3.8 & 44.1 & 0.977 & 0.987 & 0.685 \\
\hline \multirow[t]{2}{*}{ IL-C } & $M A T 1-1$ & 26 & 14 & 3.26 & 26 & 0.962 & 0.673 & 3.21 & 22.7 & 0.956 & 0.918 & 0.676 \\
\hline & MAT1-2 & 22 & 14 & 3.09 & 22 & 0.955 & 0.688 & 3.06 & 20.6 & 0.951 & 0.96 & 0.684 \\
\hline \multirow[t]{2}{*}{ Total } & MAT1-1 & 355 & 355 & 5.87 & 355 & 0.997 & 0.719 & 5.85 & 335 & 0.997 & 0.964 & 0.718 \\
\hline & MAT1-2 & 384 & 353 & 5.95 & 384 & 0.997 & 0.717 & 5.92 & 355 & 0.997 & 0.949 & 0.718 \\
\hline Grand total & $\ldots$ & 739 & 363 & 6.61 & 739 & 0.999 & 0.718 & 6.58 & 688 & 0.999 & 0.955 & 0.719 \\
\hline
\end{tabular}

a Populations (Pop) AL-F, AL-L, GA-B, KS-C, LA-P, MS-R, FL-M, OK-B, GA-T, TX-B, and IL-C from Fairhope, AL; Lowndesboro, AL; Byron, GA; Chetopa,

KS; Powhatan, LA; Raymond, MS; Monticello, FL; Burneyville, OK; Tifton, GA; Bastrop, TX; and Carlyle, IL, respectively.

b Multilocus genotypes (MLG) = genotypic richness.

${ }^{\mathrm{c}}$ Expected multilocus genotypes (eMLG) $=$ approximates the number of genotypes that would be expected at the largest, shared sample size based on rarefaction (Grünwald et al. 2003).

d The Shannon-Weiner index (SW) (Shannon 2001) described the genetic diversity in the populations, with higher numbers indicating greater diversity (it is a measure of both richness and evenness).

e Stoddart and Taylor's index of diversity (ST) (Stoddart and Taylor 1988) measures genotypic diversity.

f Simpson's index (SI) (Simpson 1949) is based on the probability of two randomly selected individuals being the same (a number close to '1' indicates a low probability that two individuals will be the same).

g Nei's unbiased gene diversity (Nei) (Nei 1978) is based on the allele frequencies. All analyses were performed using the R package poppr (Kamvar et al. 2014) for all isolates and the clone-corrected data.

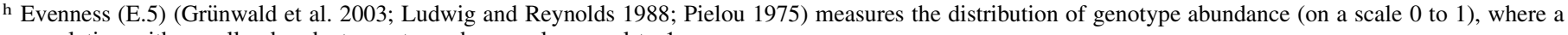
population with equally abundant genotypes has a value equal to 1 . 
polycyclic nature. Although a sexual cycle of $V$. effusa has never been identified, the presence of opposite mating types and the genetic diversity observed in populations of $V$. effusa (Bock et al. 2017b) is indicative of a sexually active, heterothallic pathogen.

The genetic architecture associated with gene organization and content of the MAT loci can vary but many heterothallic ascomycetes have APN2 encoding a DNA lyase and SLA2 encoding a cytoskeletal protein associated near or flanking the MAT genes (Debuchy and Turgeon 2006). The gene organization surrounding the MAT idiomorphs of Dothideomycetes most commonly have $A P N 2$ gene present but more variation is seen with the other flanking gene, because $S L A 2, G A P$ (encodes GTPase-activating protein), $P P O$ (encodes pyridoxamine phosphate oxidase), and a gene encoding a protein containing a $\mathrm{PH}$ domain have been identified (Chilvers et al. 2014; Cozijnsen and Howlett 2003; Pearce et al. 2016; Wang et al. 2016). The MAT idiomorphs of $V$. effusa and $V$. inaequalis have a similar gene organization, where each $M A T$ gene is flanked by APN2 encoding a DNA lyase and a gene encoding a hypothetical protein with sequence similarity to proteins containing a PH domain. However, an InterProScan of the hypothetical protein of $V$. effusa did not reveal a PH domain (IPR011993). The dothideomycete Phyllosticta citricarpa (family Botryosphaeriaceae), cause of citrus black spot, also has mating type organization similar to that described for Venturia spp. (Wang et al. 2016) but varies with the orientation of the MAT genes with respect to the flanking genes.

The frequency of the $M A T$ genes was established at multiple spatial scales in the southeastern region of the United States (784 isolates). The clone-corrected data showed that MAT frequencies were in equilibrium at the regional scale. This is despite one orchard (GA-B) within which trees had populations of $V$. effus $a$ at frequencies of the MAT idiomorphs that significantly deviated from 1:1 (based on both the clone-corrected and all data). Therefore, no compelling evidence is present to reject the null hypothesis of equilibrium overall, which is consistent with frequency-dependent selection (May et al. 1999). The disequilibrium of mating types in occasional populations has been noted before in other plant pathosystems (Linde et al. 2003; Sommerhalder et al. 2006). Thus, the approximately 1:1 ratio of MAT1-1 and MAT1-2 idiomorphs is indicative of random mating in $V$. effusa. This result is consistent with many other heterothallic ascomycete fungi where mating types have been characterized and random mating is known to occur (Chen and McDonald 1996; Dale et al. 2011; Hayden and Howlett 2005; Keller et al. 1997; Linde et al. 2002; Rau et al. 2005; Tenzer and Gessler 1999). Furthermore, populations of V. effusa are known to have characteristics of a sexually recombining fungus; it is genetically diverse and much of the population genetic diversity is at a small spatial scale and, although linkage disequilibrium exists, many pairs of loci are at equilibrium (Bock et al. 2014a,b, 2016a, 2017b). Also, the populations of $V$. effusa based on mating type in this study were deemed to be similarly diverse and had the same eMLG $(n=14)$ after rarefaction, indicating the same genotypic richness regardless of population or mating type. However, some fungal pathogens exhibit a skew in mating type in some populations, even when the pathogen is known to have a sexual cycle, whereby the incidence of a sexual stage may occur at a frequency or scale that can result in clonality and linkage disequilibrium, yet present substantial genetic diversity (Henk et al. 2012; Horn et al. 2016; Moore et al. 2013). Reproductive mechanisms occur in these populations to ensure that deleterious mutations do not build up in an irreversible manner. With $V$. effusa, there remains a possibility that other processes such as mitotic recombination might explain the observed characteristics of genetic diversity (Pontecorvo 1956); however, the MAT ratio described in this study is indicative of an unidentified sexual stage that occurs frequently enough to maintain equilibrium. The majority of the data, both clone and nonclone corrected, at the region, orchard, and tree scales, support equilibrium of mating type. These results are in agreement with similar observations on other sexually reproducing pathogens where clonality has been observed at small spatial scales (Chen and McDonald 1996; Douhan et al. 2002; Linde et al. 2002; Sommerhalder et al. 2006). This has been hypothesized to occur due to local dispersal from sites of earlier infections, and is consistent with what is known regarding local dispersal of conidia of $V$. effusa.

The fact that no sexual stage has yet been found for $V$. effus $a$ could be due to the sexual cycle occurring on different hosts. The pear scab pathogen ( $V$. pirina) has been demonstrated to have the capacity to undergo its sexual cycle on senescing and dead leaves of apple (Stehmann et al. 2001). It is possible that $V$. effusa may undergo the sexual cycle on related, widely distributed species of Carya, some of which are described as hosts (Schubert et al. 2003; Winter 1885). Furthermore, most pecan orchards are clonal but wild stands and native seedling orchards will have a diversity of genotypes, and it is not inconceivable that certain genotypes might more readily support the sexual stage. However, in all orchard populations, genetic diversity was similar regardless of source (cultivar) population (Bock et al. 2017b) or whether they were from the MAT1-1 or MAT1-2 subpopulations, and in the region as a whole, which provided further evidence that the two subpopulations share and undergo assortment of genetic material. Not unexpectedly, there were observable effects of sample size, and measures of diversity increased for both $M A T$ subpopulations with the scale of the population (Grünwald et al. 2003).

Some related fungal pathogens such as $Z$. tritici that were initially thought to go through a sexual stage during a saprobic phase in the lifecycle have since been shown to undergo the sexual cycle throughout the entire year (Zhan et al. 1998). However, others appear to have a more seasonal cycle. The closely related $V$. inaequalis on apple (Bock et al. 2016a; Schubert et al. 2003; Seyran et al. 2010a) produces ascospores during the spring that develop slowly over winter on colonized leaf litter (MacHardy 1996). Oculimacula spp. on cereals produce ascospores from stubble during the spring (Dyer et al. 2001). Pecan scab develops not only on leaflets but also on the rachis, shoots, and fruit (Demaree 1924). Leaf material generally breaks down fairly rapidly; however, the fruit shucks, rachis, and shoots do not break down as rapidly as the leaves, and would provide a basis for a saprobic phase of $V$. effusa. The apparent equilibrium of the MAT idiomorphs provides impetus to a renewed effort to search for a sexual stage of $V$. effusa in both the field and lab. Once a sexual stage is identified and understood, it may provide further opportunity to manage the disease, and will allow the genetics of the fungus to be explored in paired crosses, opening a new dimension of study in relation to the host.

\section{ACKNOWLEDGMENTS}

We thank N. Yadav, T. Endalew, M. Zhang, W. Evans, and M. Hotchkiss for their contributions to this work. This article reports the results of research only. Mention of a trademark or proprietary product is solely for the purpose of providing specific information and does not constitute a guarantee or warranty of the product by the U.S. Department of Agriculture and does not imply its approval to the exclusion of other products that may also be suitable.

\section{LITERATURE CITED}

Altschul, S. F., Gish, W., Miller, W., Myers, E. W., and Lipman, D. J. 1990. Basic local alignment search tool. J. Mol. Biol. 215:403-410.

Arie, T., Christiansen, S., Yoder, O., and Turgeon, B. 1997. Efficient cloning of ascomycete mating type genes by PCR amplification of the conserved MAT HMG box. Fungal Genet. Biol. 21:118-130.

Bock, C. H., Brenneman, T. B., Wood, B. W., and Stevenson, K. L. 2017a. Challenges of managing disease in tall orchard trees-Pecan scab, a case study. CAB Rev. 12:1-18.

Bock, C. H., Chen, C., Yu, F., Stevenson, K. L., Arias, R., and Wood, B. W. 2016a. Characterization of microsatellites in Fusicladium effusum, cause of pecan scab. For. Pathol. 46:600-609. 
Bock, C. H., Chen, C., Yu, F., Stevenson, K. L., and Wood, B. W. 2016b. Draft genome sequence of Fusicladium effusum, cause of pecan scab. Stand. Genomic Sci. 11:36.

Bock, C. H., Endalew, T., Biswas, B., Yadav, A., Sitther, V., Hotchkiss, M. W., Stevenson, K. L., and Wood, B. W. 2014a. A comparison of UP-PCR and RAPD markers to study genetic diversity of Fusicladium effusum (G. Winter), cause of pecan scab. For. Pathol. 44:266-275.

Bock, C. H., Hotchkiss, M. W., Young, C. A., Charlton, N. D., Mattupalli, C., Stevenson, K. L., and Wood, B. W. 2017b. Population genetic structure of Venturia effusa, cause of pecan scab, in the southeastern United States. Phytopathology 107:607-619.

Bock, C. H., Wood, B. W., Stevenson, K. L., and Arias, R. 2014b. Genetic diversity and population structure of Fusicladium effusum on pecan in the United States. Plant Dis. 98:916-923.

Brock, J., and Brenneman, T. B. 2013. Pecan. Page 14 in: UGA Ext. Annu. Publ. 102-5, University of Georgia.

Brock, J., and Brenneman, T. B. 2014. Pecan. Page 14 in: UGA Ext. Annu. Publ. 102-7, University of Georgia.

Brock, J., and Brenneman, T. B. 2015. Pecan. Page 14 in: UGA Cooperative Ext. Annu. Publ. 102-8, University of Georgia.

Chen, R.-S., and McDonald, B. A. 1996. Sexual reproduction plays a major role in the genetic structure of populations of the fungus Mycosphaerella graminicola. Genetics 142:1119-1127.

Chilvers, M. I., Jones, S., Meleca, J., Peever, T. L., Pethybridge, S. J., and Hay, F. S. 2014. Characterization of mating type genes supports the hypothesis that Stagonosporopsis chrysanthemi is homothallic and provides evidence that Stagonosporopsis tanaceti is heterothallic. Curr. Genet. 60:295-302.

Conner, P. J., and Stevenson, K. L. 2004. Pathogenic variation of Cladosporium caryigenum isolates and corresponding differential resistance in pecan. HortScience 39:553-557.

Converse, R. 1960. Physiologic specialization of Fusicladium effusum and its evaluation in vitro. Phytopathology 50:527-531.

Cozijnsen, A. J., and Howlett, B. J. 2003. Characterisation of the mating-type locus of the plant pathogenic ascomycete Leptosphaeria maculans. Curr. Genet. 43:351-357.

Dale, A., Lewis, K., and Murray, B. 2011. Sexual reproduction and gene flow in the pine pathogen Dothistroma septosporum in British Columbia. Phytopathology 101:68-76.

Debuchy, R., and Turgeon, B. 2006. Mating-type structure, evolution, and function in Euascomycetes. Pages 293-323 in: Growth, Differentiation and Sexuality. U. Kües and R. Fischer, eds. Springer, Berlin, Heidelberg.

Demaree, J. B. 1924. Pecan scab with special reference to sources of the early spring infections. J. Agric. Res. 28:321-330.

Deng, C. H., Plummer, K. M., Jones, D. A., Mesarich, C. H., Shiller, J., Taranto, A. P., Robinson, A. J., Kastner, P., Hall, N. E., and Templeton, M. D. 2017. Comparative analysis of the predicted secretomes of Rosaceae scab pathogens Venturia inaequalis and $V$. pirina reveals expanded effector families and putative determinants of host range. BMC Genomics 18:339.

Douhan, G., Murray, T., and Dyer, P. 2002. Species and mating-type distribution of Tapesia yallundae and T. acuformis and occurrence of apothecia in the US Pacific Northwest. Phytopathology 92:703-709.

Dyer, P., Bateman, G., and Wood, H. 2001. Development of apothecia of the eyespot pathogen Tapesia on cereal crop stubble residue in England. Plant Pathol. 50:356-362.

Everitt, B. S. 1992. The Analysis of Contingency Tables. CRC Press, London.

Goff, W. D., McVay, J. R., and Gazaway, W. S. 1989. Pecan Production in the Southeast: A Guide for Growers. Alabama Cooperative Extension Service, Auburn University, AL.

Gottwald, T., and Bertrand, P. 1982. Patterns of diurnal and seasonal airborne spore concentrations of Fusicladium effusum and its impact on a pecan scab epidemic. Phytopathology 72:330-335.

Gottwald, T., and Bertrand, P. 1983. Effect of time of inoculation with Cladosporium caryigenum on pecan scab development and nut quality. Phytopathology 73:714-718.

Grünwald, N. J., Goodwin, S. B., Milgroom, M. G., and Fry, W. E. 2003. Analysis of genotypic diversity data for populations of microorganisms. Phytopathology 93:738-746.

Hayden, H. L., and Howlett, B. J. 2005. Genetic structure of a population of the fungus Leptosphaeria maculans in a disease nursery of Brassica napus in Australia. Curr. Genet. 48:142-149.

Henk, D. A., Shahar-Golan, R., Devi, K. R., Boyce, K. J., Zhan, N., Fedorova, N. D., Nierman, W. C., Hsueh, P.-R., Yuen, K.-Y., and Sieu, T. P. 2012. Clonality despite sex: The evolution of host-associated sexual neighborhoods in the pathogenic fungus Penicillium marneffei. PLoS Pathog. 8: e1002851

Horn, B. W., Gell, R. M., Singh, R., Sorensen, R. B., and Carbone, I. 2016. Sexual reproduction in Aspergillus flavus sclerotia: Acquisition of novel alleles from soil populations and uniparental mitochondrial inheritance. PloS One 11:e0146169.

Horn, B. W., Moore, G. G., and Carbone, I. 2009. Sexual reproduction in Aspergillus flavus. Mycologia 101:423-429.

Jones, P., Binns, D., Chang, H.-Y., Fraser, M., Li, W., McAnulla, C., McWilliam, H., Maslen, J., Mitchell, A., and Nuka, G. 2014. InterProScan 5: Genomescale protein function classification. Bioinformatics 30:1236-1240.

Kamvar, Z. N., Tabima, J. F., and Grünwald, N. J. 2014. Poppr: An R package for genetic analysis of populations with clonal, partially clonal, and/or sexual reproduction. PeerJ 2:e281.

Keitt, G. W., and Palmiter, D. 1938. Heterothallism and variability in Venturia inaequalis. Am. J. Bot. 25:338-345.

Keller, S., McDermott, J., Pettway, R., Wolfe, M., and McDonald, B. 1997. Gene flow and sexual reproduction in the wheat glume blotch pathogen Phaeosphaeria nodorum (anamorph Stagonospora nodorum). Phytopathology 87: 353-358.

Latham, A. 1982. Effects of some weather factors and Fusicladium effusum conidium dispersal on pecan scab occurrence. Phytopathology 72: $1339-1345$.

Linde, C. C., Zala, M., Ceccarelli, S., and McDonald, B. A. 2003. Further evidence for sexual reproduction in Rhynchosporium secalis based on distribution and frequency of mating-type alleles. Fungal Genet. Biol. 40: 115-125.

Linde, C. C., Zhan, J., and McDonald, B. A. 2002. Population structure of Mycosphaerella graminicola: From lesions to continents. Phytopathology 92:946-955.

Ludwig, J. A., and Reynolds, J. F. 1988. Statistical Ecology: A Primer in Methods and Computing. John Wiley \& Sons, New York.

MacHardy, W. E. 1996. Apple Scab: Biology, Epidemiology, and Management. American Phytopathological Society Press, St. Paul, MN.

May, G., Shaw, F., Badrane, H., and Vekemans, X. 1999. The signature of balancing selection: Fungal mating compatibility gene evolution. Proc. Natl. Acad. Sci. USA 96:9172-9177.

Moore, G. G., Elliott, J. L., Singh, R., Horn, B. W., Dorner, J. W., Stone, E. A., Chulze, S. N., Barros, G. G., Naik, M. K., and Wright, G. C. 2013. Sexuality generates diversity in the aflatoxin gene cluster: Evidence on a global scale. PLoS Pathog. 9:e1003574.

Nei, M. 1978. Estimation of average heterozygosity and genetic distance from a small number of individuals. Genetics 89:583-590.

Nordberg, H., Cantor, M., Dusheyko, S., Hua, S., Poliakov, A., Shabalov, I., Smirnova, T., Grigoriev, I. V., and Dubchak, I. 2014. The genome portal of the Department of Energy Joint Genome Institute: 2014 updates. Nucleic Acids Res. 42:D26-D31.

O'Gorman, C. M., Fuller, H. T., and Dyer, P. S. 2009. Discovery of a sexual cycle in the opportunistic fungal pathogen Aspergillus fumigatus. Nature 457:471-474.

Peakall, R., and Smouse, P. E. 2006. GENALEX 6: Genetic analysis in Excel. Population genetic software for teaching and research. Mol. Ecol. Notes 6: 288-295.

Peakall, R., and Smouse, P. E. 2012. GenAlEx 6.5: Genetic analysis in Excel. Population genetic software for teaching and research-An update. Bioinformatics 28:2537-2539.

Pearce, T. L., Scott, J. B., Hay, F. S., and Pethybridge, S. J. 2016. Mating-type gene structure and spatial distribution of Didymella tanaceti in pyrethrum fields. Phytopathology 106:1521-1529.

Penselin, D., Münsterkötter, M., Kirsten, S., Felder, M., Taudien, S., Platzer, M., Ashelford, K., Paskiewicz, K. H., Harrison, R. J., and Hughes, D. J. 2016. Comparative genomics to explore phylogenetic relationship, cryptic sexual potential and host specificity of Rhynchosporium species on grasses. BMC Genomics 17:953.

Pielou, E. 1975. Ecology Diversity. J. Wiley and Sons, New York.

Pöggeler, S. 2001. Mating-type genes for classical strain improvements of ascomycetes. Appl. Microbiol. Biotechnol. 56:589-601.

Pontecorvo, G. 1956. The parasexual cycle in fungi. Annu. Rev. Microbiol. 10: 393-400.

Priyam, A., Woodcroft, B. J., Rai, V., Munagala, A., Moghul, I., Ter, F., Gibbins, M. A., Moon, H., Leonard, G., and Rumpf, W. 2015. Sequenceserver: A modern graphical user interface for custom BLAST databases. bioRxiv Article 033142 .

Ramirez-Prado, J. H., Moore, G. G., Horn, B. W., and Carbone, I. 2008. Characterization and population analysis of the mating-type genes in Aspergillus flavus and Aspergillus parasiticus. Fungal Genet. Biol. 45:1292-1299.

Rau, D., Maier, F. J., Papa, R., Brown, A. H., Balmas, V., Saba, E., Schaefer, W., and Attene, G. 2005. Isolation and characterization of the mating-type locus of the barley pathogen Pyrenophora teres and frequencies of matingtype idiomorphs within and among fungal populations collected from barley landraces. Genome 48:855-869.

R Core Team. 2012. R: A Language and Environment for Statistical Computing. R Foundation for Statistical Computing, Vienna. 
Rossman, A. Y., Allen, W. C., and Castlebury, L. A. 2016. New combinations of plant-associated fungi resulting from the change to one name for fungi. IMA Fungus 7:1-7.

Schubert, K., Rischel, A., and Braun, U. 2003. A monograph of Fusicladium s. lat.(hyphomycetes). Schlechtendalia (Halle) 9:1-132.

Seyran, M., Brenneman, T. B., and Stevenson, K. L. 2010a. A rapid method to monitor fungicide sensitivity in the pecan scab pathogen, Fusicladium effusum. Crop Prot. 29:1257-1263.

Seyran, M., Nischwitz, C., Lewis, K. J., Gitaitis, R. D., Brenneman, T. B., and Stevenson, K. L. 2010b. Phylogeny of the pecan scab fungus Fusicladium effusum $\mathrm{G}$. Winter based on the cytochrome b gene sequence. Mycol. Prog. 9:305-308.

Shannon, C. E. 2001. A mathematical theory of communication. ACM SIGMOBILE Mob. Comput. Commun. Rev. 5:3-55.

Simpson, E. H. 1949. Measurement of diversity. Nature 163:688.

Solovyev, V., Kosarev, P., Seledsov, I., and Vorobyev, D. 2006. Automatic annotation of eukaryotic genes, pseudogenes and promoters. Genome Biol. $7:$ S10

Sommerhalder, R. J., McDonald, B. A., and Zhan, J. 2006. The frequencies and spatial distribution of mating types in Stagonospora nodorum are consistent with recurring sexual reproduction. Phytopathology 96:234-239.
Stehmann, C., Pennycook, S., and Plummer, K. M. 2001. Molecular identification of a sexual interloper: The pear pathogen, Venturia pirina, has sex on apple. Phytopathology 91:633-641.

Stevenson, K. L., and Bertrand, P. 2001. Within-season dynamics of yield loss due to pecan scab fruit infections. (Abstr.) Phytopathology 91:S85.

Stoddart, J. A., and Taylor, J. F. 1988. Genotypic diversity: Estimation and prediction in samples. Genetics 118:705-711.

Tenzer, I., and Gessler, C. 1999. Genetic diversity of Venturia inaequalis across Europe. Eur. J. Plant Pathol. 105:545-552.

Turgeon, B. G., and Yoder, O. 2000. Proposed nomenclature for mating type genes of filamentous ascomycetes. Fungal Genet. Biol. 31:1-5.

Wang, N.-Y., Zhang, K., Huguet-Tapia, J. C., Rollins, J. A., and Dewdney, M. M. 2016. Mating type and simple sequence repeat markers indicate a clonal population of Phyllosticta citricarpa in Florida. Phytopathology 106: 1300-1310.

Winter, G. 1885. New North America fungi. J. Mycol. 1:101-102.

Worley, R. 2002. Compendium of Pecan Production and Research. Edwards Brothers, Ann Arbor, MI.

Zhan, J., Mundt, C., and McDonald, B. 1998. Measuring immigration and sexual reproduction in field populations of Mycosphaerella graminicola. Phytopathology 88:1330-1337. 